\title{
COMPRESSED AIR SUPPLY AND DISTRIBUTION SYSTEM FOR AVIATION LABORATORIES AND WIND TUNNELS
}

\section{Eukasz Kędzierski}

Lab Maintenance and Development, Institute of Aviation

al. Krakowska 110/114, 02-256 Warsaw, Poland

Institute of Theory of Electrical Engineering, Measurement and Information Systems, Faculty of Electrical Engineering, Warsaw University of Technology,

Pl. Politechniki 1, 00-661 Warsaw, Poland

lukasz.kedzierski@ee.pw.edu.pl

\section{Abstract}

The purpose of this text is to demonstrate an operation of a compressed air system designed for high air flow laboratories and wind tunnels. Development of such air system is a challenge due to unusual requirements (simultaneous supply of several users having different requirements and necessity to provide extremely high flows) which have to be address by means of adequate compressed air storage capacity and sophisticated control system. Each stage of the design process is going to be described, focusing on the selection of air compressors, air receivers and air dryers, followed by an insight into a development of the control system. The air system being described in this paper was successfully implemented at the Institute of Aviation in Warsaw improving the quality of the compressed air supply and simplifying the research planning.

Keywords: compressed, air, laboratory, wind, tunnel.

\section{INTRODUCTION}

Many books, guides and publications have been written regarding the design of compressed air supply and distribution systems dedicated for manufacturing purposes. These texts are focusing mainly on efficiency $[1,2]$ as the compressed air is one of the most expensive mediums to produce because of losses due to heat generated during the adiabatic process (air compression happens so quickly that the process can be consider as instantaneous [3]), not to mention the following losses due to leaks. However they come short when it comes to unusual compressed air applications such as aviation laboratories and wind tunnels where high air flows and flexibility of the system are necessary and the cost efficiency is less of an issue. This article provides an insight into an existing compressed air system that has been operating now for couple of years in Institute of Aviation in Warsaw supplying the compressed air to several aviation laboratories and wind tunnels. 


\section{AIR COMPRESSORS}

Similar to the compressed air system designated for manufacturing purposes, the design stage of the compressed air system starts with choosing the right type of compressor for the application. When it comes to aviation laboratories and wind tunnels the job is straight forward as the maximum working pressure rarely exceeds $10 \mathrm{bar}(\mathrm{g})$. With that in mind the choice of the right compressor can be made regardless of the maximum pressure achievable by a particular type of the compressor since all the machines available on market, whether it should be reciprocating compressor, rotary screw compressor, rotary vane compressor or centrifugal compressor, can easily reach $10 \mathrm{bar}(\mathrm{g})$.

While the maximum working pressure requirements in case of aviation laboratories and wind tunnels are pretty easy to fulfill, finding the perfect balance between the maximum continuous flow requirements and easement of capacity control are more of a challenge. The flow requirements of wind tunnels [4],which can be as high as tens of $\mathrm{kg} / \mathrm{s}$, simply cannot be met by a compressed air system of a sensible size therefore they require very high storage capacity. As for the laboratories in theInstitute of Aviation, the requirements have been set on $2 \mathrm{~kg} / \mathrm{s}$ of continuous air flow at $8 \mathrm{bar}(\mathrm{g})$, keeping in mind that any flows exceeding this threshold could be temporally met by the containers normally designated for wind tunnels.

As a result rotary screw compressors has been chosen based on their efficiency, easy application of variable frequency drives for capacity control, relatively low (when compared with other types of compressors) noise and vibration and finally because of their simple design which helps to reduce the initial cost and later maintenance costs [5]. To best accommodate the diverse flow demands which could vary greatly depending on a particular laboratoryas well as to allow using the compressed air of different parameters by separate users simultaneously, 4 rotary screw compressors were installed at Institute of Aviation, 2 of which have been equipped with a variable frequency drive. Total electric power of the machines chosen summed up to around $1 \mathrm{MW}$ providing the continuous air flow reaching $130 \mathrm{~m}^{3} / \mathrm{min}$ which corresponds to just little over the initial requirement of $2 \mathrm{~kg} / \mathrm{s}$.

\section{AIR RECEIVERS}

Compressed air receivers are as much a vital element of the system as the compressors themselves. Their primary role is to supply the air to the system in the event of peak demand periods when more air is being used by the users than the compressors produce at the same time [6]. They act the same way as capacitors do in electronic circuits but instead of the electric charge they store air. They help to maintain a steady flow of air in the system absorbing any pulsations, either they are caused by the excessive production of compressed air by the compressor or the excessive use of the air by the users. Finally in the systems where the compressors are not equipped with the variable frequency drives they prevent, if properly sized, the short cycling of the compressors which is caused by too frequent switching between load and unload state.

Air receivers of several cubic meters size are a common industry practice. Considering that they store the air at high pressures much thought should be given to their safety as they contain a considerable amount of energy. Usual practice is to install a safety valve of opening pressure specified to the maximum operating pressure of the system and maximum air flow capacity of the compressors. This approach ensures that in case of exceeding the maximum pressure all the excessive air produced continuously by the compressors shall be released from the system and therefore not causing the air receiver to explode. Safety of air receivers is a subject to local regulations and periodical control as if left unattended they could be dangerous leading to the serious financial loses and even to a loss of human life. 
Air receivers size and quantity is system specific. The most versatile designs will have individual receivers for each compressor at the supply side and individual receiver for each significant user at the receiving side (Figure 1). However, if there's no need for different pressures being supplied by each compressor, all the compressor could have just one big air receiver (Figure 2). Similarly, if the fluctuations in the system are not critical for a particular user, installing an air receiver at that user receiving side might be omitted.

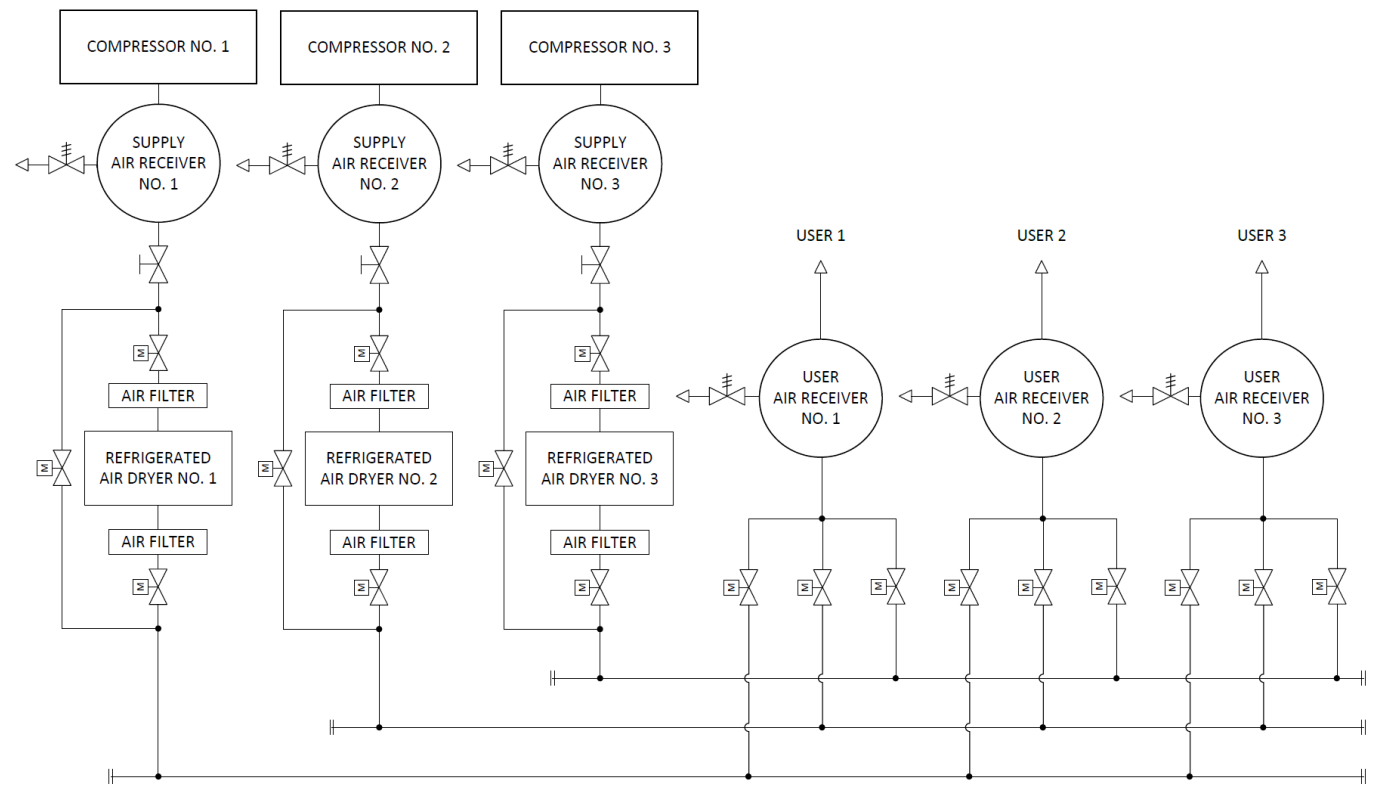

Fig. 1. Compressed air system with individual air receivers for each individual compressor and each significant user

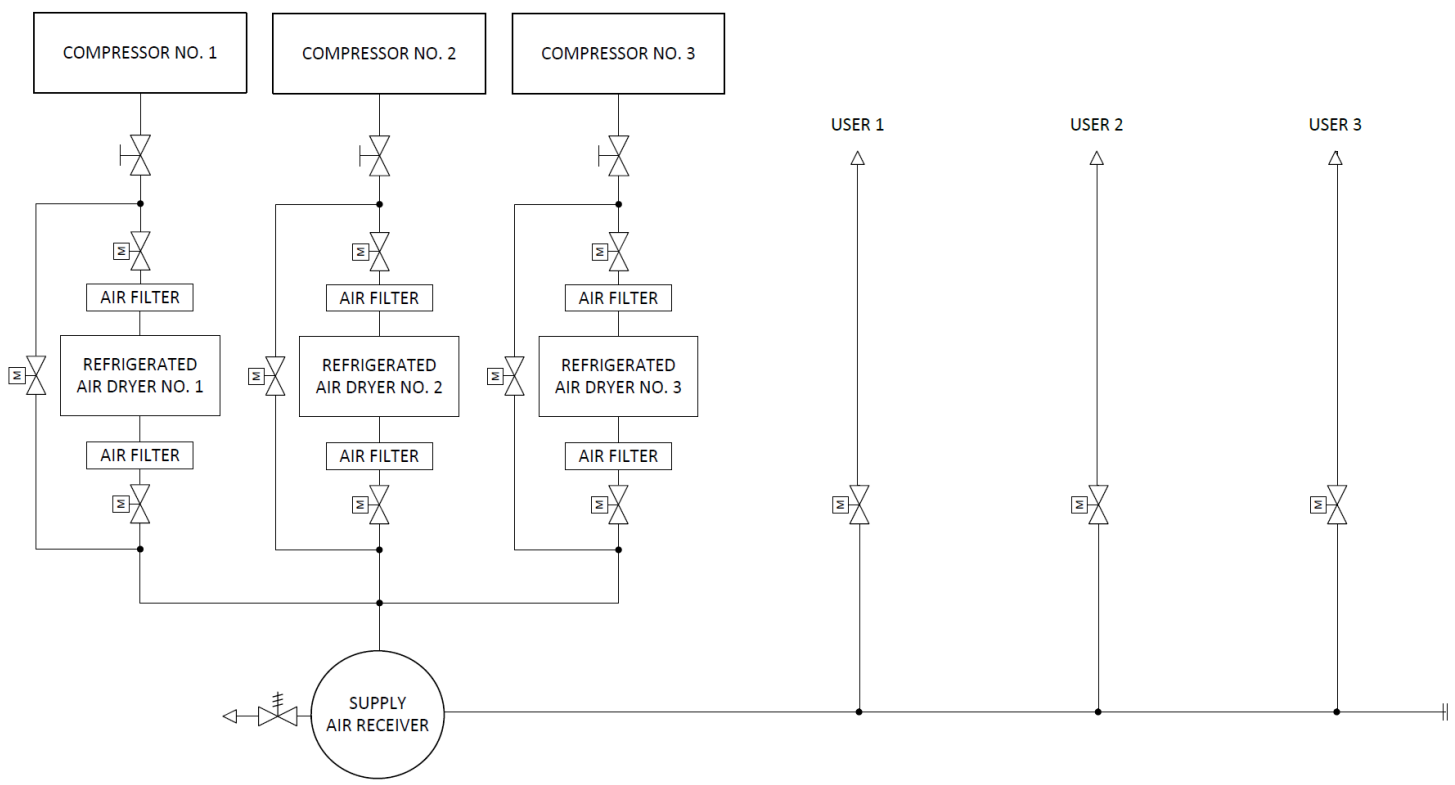

Fig. 2. Compressed air system with only one air receiver 
Sizing is done by calculating the additional airflow $\mathrm{f}_{\min }\left[\mathrm{m}^{3} / \mathrm{min}\right]$ that has to be supplied for a given time period $\mathrm{t}[\mathrm{min}]$ causing a pressure drop of $\Delta \mathrm{P}[\mathrm{bar}]$ in the system. The resulting receiver volume $\mathrm{V}\left[\mathrm{m}^{3}\right]$ is given by the following equation $[6]$ :

$$
V=\frac{f_{\min } \cdot t}{\Delta P}
$$

For the compressed air system in the Institute of Aviation the sizing of the supply air receivers has been performed in such a way that for each compressor the air receiver assigned to this compressor should be capable of supplying additional air flow of $10 \mathrm{~m}^{3} / \mathrm{min}$ for 1 minute, causing a 2 bar pressure drop (from a standard working pressure $8 \mathrm{bar}(\mathrm{g})$ to minimum working pressure $6 \mathrm{bar}(\mathrm{g})$ ). As a result 3 air receivers of 5 cubic meters volume each were delivered and installed. When sizing air receivers one should keep in mind that long pipelines also act as a storage tank. This could easily be shown when we imagine for example a 100 meters long pipeline of $200 \mathrm{~mm}$ diameter which volume exceeds 3 cubic meters.

As mentioned before, operation of wind tunnels requires air flows that exceeds by several times a continuous air flow capacity of the installed compressors. Therefore a huge air receivers are needed on the user side to enable the operation of these wind tunnels. Two spherical air storage units, each of 1400 cubic meters volume and capable of storing compressed air at $8 \mathrm{bar}(\mathrm{g})$ are the heart of the compressed air system in the Institute of Aviation. All the compressed air being produced by the compressors can be directed to these air receivers and each laboratory and wind tunnel can use this stored air for its current research needs. Having a storage capacity of 2800 cubic meters allows to reach air flows that are only limited by the pipeline diameter. Further advantage ofthis solution is the elimination of the need for individual air receivers on the user side. However, there are several drawbacks of having such a big storage units. First of them is the time it takes to pressurize these air receivers. As could be easily calculated, to reach the maximum allowable pressure of $8 \mathrm{bar}(\mathrm{g})$ it takes almost 3 hours of full-load operation of all the compressors capable of producing a $130 \mathrm{~m}^{3} / \mathrm{min}$ of continuous air flow. Therefore it's necessary to have the by-pass lines supplying the air to the end users when using the spherical air storage units is not absolutely necessary. This solution requires a much more complex control system, not to mention additional valves and hundreds of meters of additional pipelines. Second drawback is the safety issue. Considering the volume and the maximum pressure of the stored air, such air receivers are a potential life hazard. Having that in mind their maintenance has to be handled with the utmost care and attention to details.

\section{AIR TREATMENT}

To ensure long lasting and reliable operation of the compressed air system, the air being produced by the compressors has to be adequately filtered and dried. Air treatment usually consist of three operations, those being mechanical filtration, drying and finally condensate removal [7], not necessarily performed in that order. Each of the aforementioned operations, except of the air drying which would be pointless to repeat, could be also performed more than once(for example air could be mechanically filtered at the compressor output then at air receiver output and finally at the refrigerant dryer output, while in the meantime the condensate shall be removed from each filter as well as from the air receiver 
and the air dryer). Condensate usually contains $99 \%$ of water and only $1 \%$ of oil, therefore oil separation from condensate is much more efficient than disposal of all condensate which has to be performed by specialized companies. The quality of air that is being received by the user could be described by 3 factors, according to Table 1.

Table 1. Air Quality classification according to ISO 8573

\begin{tabular}{|c|c|c|c|}
\hline Quality class & Particle size [microns] & Dew point $\left[{ }^{0} \mathrm{C}\right]$ at 7 bar $(\mathrm{g})$ & Oil content $\left[\mathrm{mg} / \mathrm{m}^{3}\right]$ \\
\hline 1 & 0.1 & -70 & 0.01 \\
\hline 2 & 1 & -40 & 0.01 \\
\hline 3 & 5 & -20 & 1 \\
\hline 4 & 15 & 3 & 5 \\
\hline 5 & 40 & 7 & 25 \\
\hline 6 & - & 10 & - \\
\hline
\end{tabular}

There are several types of compressed air dryers, the most popular being refrigerant air dryers, usually capable of reaching dew point temperature below $3{ }^{\circ} \mathrm{C}$, and adsorption air dryers, usually capable of reaching dew point temperature below $-40^{\circ} \mathrm{C}$. Depending on the regeneration method, there are several types of adsorption dryers, however it's not a point of this article to describe the principle of their operation. To facilitate the system flexibility to diverse user needs in the compressed air system in the Institute of Aviation both types (refrigerant and adsorption) of dryers were installed. As a result each laboratory and wind tunnel can be supplied with three types (only one type at a time) of air - not dried, with $+3^{\circ} \mathrm{C}$ dew point temperature or $-40^{\circ} \mathrm{C}$ dew point temperature. The complete block diagram of the compressed air system at Institute of Aviation has been shown on Figure 3.

\section{CONTROL SYSTEM}

Control of the compressed air system at the Institute of Aviation is based on Programmable Automation Controller (PAC). There are 2 controllers working as a distributed control system - master and a slave controller. The control system attends analog and digital inputs/outputs and communicates with other devices over physical layers of RS-485 and Ethernet. The operation of the control system is being supported by a unmanaged switch, Ethernet router and a safety relay. Whole control cabinet, together with all supporting hardware, is powered by an on-line UPS capable of supplying the power for 60 minutes in case of a power failure. 


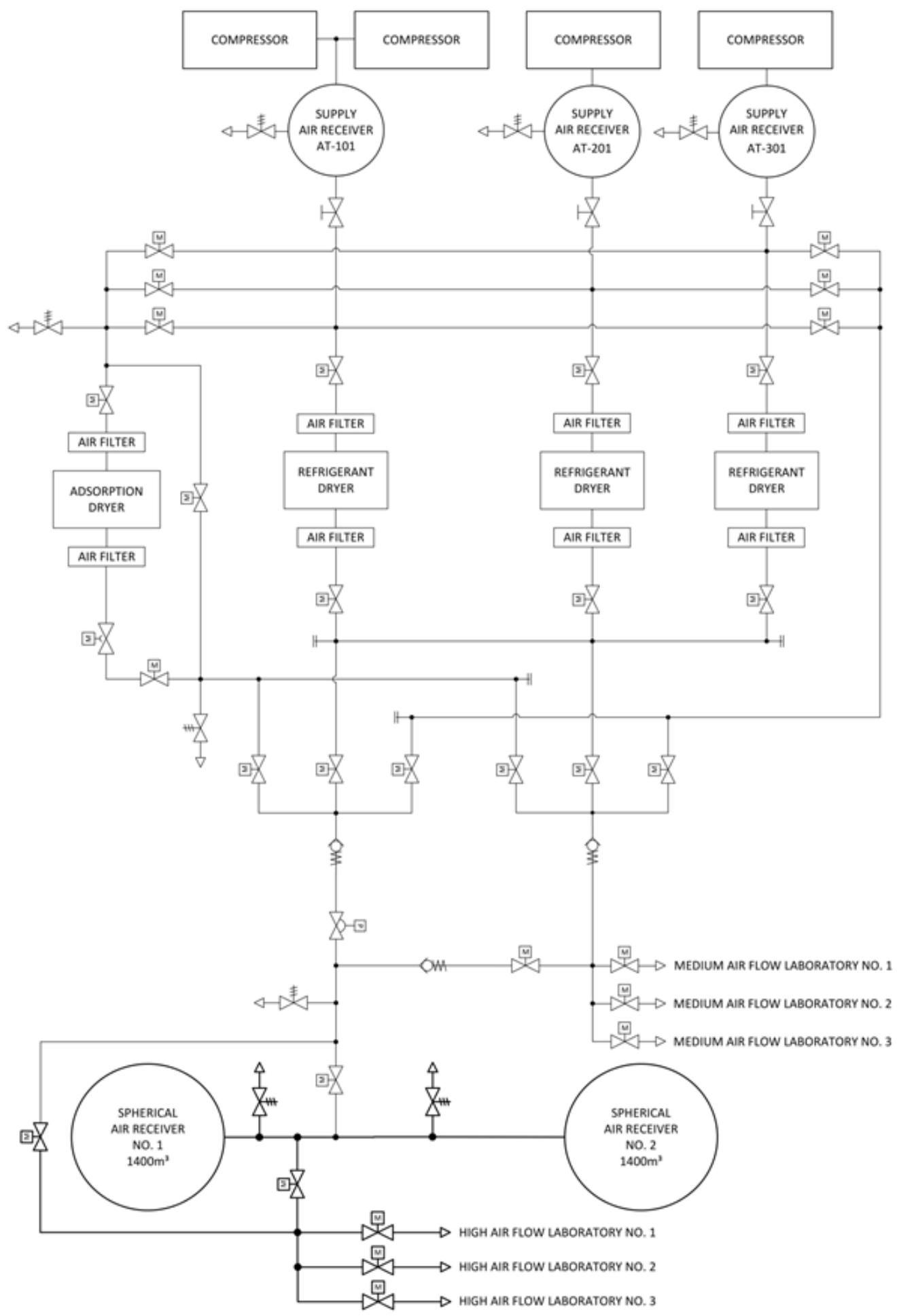

Fig. 3. Compressed air system at Institute of Aviation in Warsaw 
The following tasks are being performed by the control:

a) acquisition of analog measurements (including pressure, dew point temperature, position of control valves and others),

a) acquisition of digital measurements (including shut-off valves position, machines states and others),

b) actuators control (including control valves, shut-off valves, light columns and others),

c) communication with air compressors slave control systems over Modbus RTU by means of a RS485 serial connection; acquisition of data sent by air compressors slave control systems at and management of air compressors operation profiles,

d) communication with control panel over TCP/IP; visualization of a current state of the compressed air system in form of an interactive user interface and charts; manual operation of the compressed air system via the graphical user interface,

e) storage of averaged data in the control panel memory,

f) communication via HTTP protocol with control panels at laboratories and wind tunnels to which the compressed air is being supplied,

g) supervision of compressed air system schedule modifications considering available resources,

h) automatic control of compressed air system based on the user entries in the schedule.

Compressed air system at the Institute of Aviation can operate in the one of the following 3 modes:

a) automatic mode - remote control by autonomous execution of the schedule according to the logic implemented in the master controller,

b) manual mode - manual control performed by a user via the control panel,

c) emergency shutdown -instantaneous shutdown of the compressed air system.

The safety relay monitors all safety states (pressure switches located on critical instruments, fire detection system, position of emergency shutdown buttons, compressors faults, control system state) and in case of disruption of any such a state, emergency shutdown of the whole compressed air system is being performed. As for the state of the control system, when the master controller is turned on it synchronizes over Ethernet with the slave controller. Afterwards both controllers are continuously monitoring each other's state and in case of a fault, the execution of the emergency shutdown procedure is being performed. Compressed air system can operate safely even when the communication with the control panel is interrupted, therefore thestate of the control panel is not being monitored. After the emergency shutdown has been executed it is not possible to change the operation mode of the compressed air system. User has to acknowledge the emergency shutdown by pressing manual reset button. Only then the compressed air system can start and be reset for new parameters.

In the manual mode user can change the position of each valve and assign the operation profile for each compressor independently via control panel. Each end user is protected with its own shut-off valve, however operating compressed air system in manual mode must be performed with utmost care and awareness because of the possibility of directing the compressed air to an end user who is unprepared and unaware of that fact. Manual mode is used mostly for service purposes and to perform checks of the system that are not possible in automatic mode.

Most of the time the compressed air system operates in automatic mode. Tasks performed by compressed air system in automatic mode depend strictly on entries made by the end users in the scheduling application. Every laboratory and wind tunnel has its own control which sole purpose is the communication with the compressed air system via HTTP protocol. Current schedule is being stored 
in the master controller memory and can be accessed by the end users only through the control panel. End user can perform the following tasks:
a) logging to the system,
b) browsing through the schedule presented in a time-table form,
c) adding entries to the schedule,
d) editing own entries,
e) deleting own entries,
f) looking at the visualization of the compressed air system current status.

To add an entry to the schedule, the end user has to provide the following data:

a) minimal required flow $\mathrm{Q}\left[\mathrm{m}^{3} / \mathrm{min}\right]$,

b) minimal pressure required $\mathrm{p}_{\min }[\mathrm{bar}(\mathrm{g})]$ (system translates this value to a corresponding operation profile of the air compressors); maximum pressure $\mathrm{p}_{\max }$ is calculated by the system following the equation $\mathrm{p}_{\max }=\mathrm{p}_{\min }+0.5[\operatorname{bar}(\mathrm{g})]$,

c) dew point temperature $\left(40^{\circ} \mathrm{C},+3^{\circ} \mathrm{C}\right.$, air not dried),

d) task start time [YYYY-MM-DD HH:MM],

e) task end time [YYYY-MM-DD HH:MM],

f) compressed air source from (air compressors, spherical air storage units),

g) compressed air end destination point (spherical air storage units, each individual laboratory and each individual wind tunnel) - there are only two elements assigned to each user (spherical air storage units and the laboratory or wind tunnel this particular user is responsible for), therefore it is not possible to direct the compressed air to a place where it is not needed nor expected at the moment; spherical air storage units can be chosen either as a source or a destination point (however it is not possible to add a task for which spherical air storage units would be a source and a destination point at the same time).

All the information specified by the user in the schedule entry is being sent to the master controller. The master controller is constantly monitoring the resources that are currently being used and decides whether it is possible to reserve additional resources at the time specified by the end user. If there is not enough resource available the master controller rejects the user entry and sends back an information explaining which parameter could not be satisfied. The user then can change the parameters (reduce the minimal flow, change the dew point or match the minimal pressure of the compressed air being supplied to another user and then use the same collector) and try to add the entry again. The user cannot change the entries added by other users but can view all the parameters of such entries. Each user has his unique login and password.

In case of a malfunction of any of the devices (compressors, air dryers, valves, etc.) associated with the compressed air system, a fault condition is detected. The control system then evaluates an impact of this malfunction on the entire compressed air system and decides which entries can be continued and which has to be stopped.

The logic implemented in master controller monitors available resources and performs complex actions to sustain air delivery in case of a fault detection. Algorithm is far beyond the scope of this paper.

The last task which is being performed by the control system is a control of spherical air storage units pressurization. These containers are prone to oxidization so they have to be pressurized with the driest air possible and for this purpose the adsorption dryer is necessary. The biggest drawback of such a dryer is the fact that is has to work with a minimal pressure which in the case of the unit installed in 
the Institute of Aviation is $5 \mathrm{bar}(\mathrm{g})$. Two stage closed loop control has been implemented. Originally just one stage PID controller has been used to keep the stable pressure at the adsorption dryer with a 5.1bar(g) set point. However, the pressure drop on the control valve was a source of intense noise, especially at the beginning of the spherical air storage units pressurization when the storage units are empty and the pressure drop is at its maximum value. Short term solution to the noise problem included using a special noise reducing paint and insulation blankets on the valve itself and the pipelines around it. As the noise reduction provided by these two factors was not sufficient, the decision has been made to split the pressure drop over two control valves using two separate PID controllers (first stage PID controller to keep the pressure at the adsorption dryer at $5.1 \mathrm{bar}(\mathrm{g})$ and the second stage PID controller to keep the pressure at the second stage control valve at $2.5 \mathrm{bar}(\mathrm{g}))$. Due to the size of the spherical air storage units their pressurization is a process with a huge inertia therefore the tuning of both PID controllers had to be performed with a lot of technical expertise. Figure 4 shows the process of spherical air storage units pressurization.

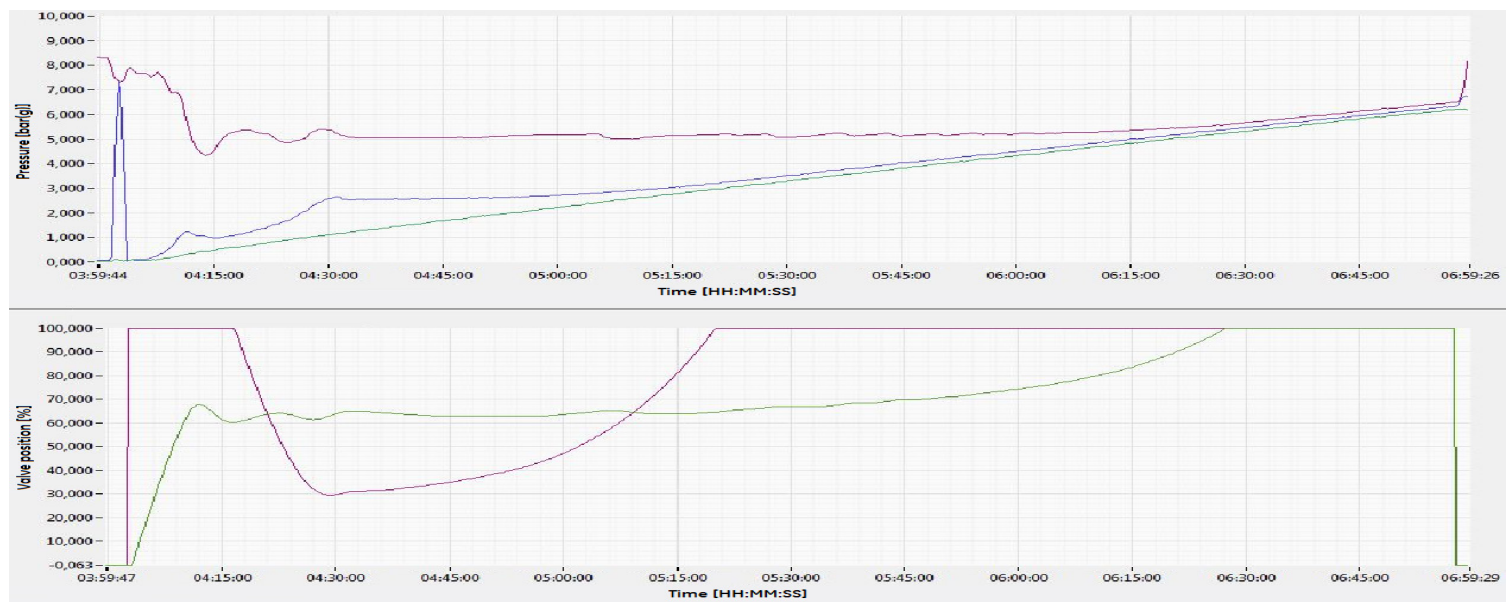

Fig. 4. Pressure at the adsorption dryer (red), pressure at the second stage control valve (blue) and pressure in the spherical air storage units (green) over time

\section{SUMMARY}

There are a lot of aspects to the design of the compressed air supply and distribution system for aviation laboratories and wind tunnels that are quite unique. The compressed air system presented in this paper may act as a guide for each step in the process of design and procurement when the common knowledge available on the subject becomes insufficient. Several key differences are setting such a system apart from the compressed air systems commonly seen in the manufacturing industry. First of these differences, and the most expensive to accomplish, is the necessity of huge air storage capacity. Careful calculations have to be made considering the maximum additional flow needed for a given time. The resulting volume should be increased by a reasonable amount to accommodate any additional future needs. Second difference is the capability to supply air dried by different means. Depending on the type of research performed, the end user may need an air with diverse dew point temperature, therefore the system has to be able to adapt to this needs. The system described in this paper, capable of supplying air dried to $-40^{\circ} \mathrm{C},+3^{\circ} \mathrm{C}$ and air not dried is just an example, however it is an example that has provensufficient in case of the Institute of Aviation. Third and the most important difference 
is the control system. Especially the schedule application is a tool that should be present at any similar system. Every end user can easily access the schedule, check the available system components (compressors, dryers, air storage units, etc.) at any point in the future and plan his research accordingly. At the same time any end user doesn't have to worry about pressure drops or supply breaks because of other users activities. Entire system is being run by the master controller which has the control over each system component and which can adapt to failures of these components making the supply and distribution of compressed air a process everybody can rely on.

\section{BIBLIOGRAPHY}

[1] "Compressed Air System Installation Guide", 2015, Kaeser Compressors Inc.

[2] "Compressed Air Manual $7^{\text {th }}$ Edition", 2010, Atlas Copco Airpower NV, Belgium.

[3] "Isothermal and Adiabatic Processes", Memorial University of Newfoundland, Department of Physics and Physical Oceanography, Physics 2053 Laboratory.

[4] Wiśniowski W., 2016, „Aerodynamic wind tunnels in Poland on the world background” (in Polish: "Tunele aerodynamiczne w Polsce na tle tuneli światowych"), Wydawnictwa Naukowe Instytutu Lotnictwa, Warsaw.

[5] Paul C. Hanlon, et al., 2001, "Compressors Handbook", New York: McGraw-Hill.

[6] "A Guide to the Construction, Installation, Operation and Maintenance of Air Receivers", 2016, Labour Department, Occupational Safety and Health Branch.

[7] "Compressed Air: Energy Efficiency Reference Guide", 2007, CEA Technologies Inc.

\section{SYSTEM WYTWARZANIA I DYSTRYBUCJI SPRĘŻONEGO POW- IETRZA DLA LABORATORIÓW BADAWCZYCH ORAZ TUNELI AERODYNAMICZNYCH}

\section{Streszczenie}

Celem tej pracy jest zaprezentowanie działania systemu wytwarzania i dystrybucji sprężonego powietrza przeznaczonego do zasilania laboratoriów badawczych oraz tuneli aerodynamicznych. Zaprojektowanie takiego systemu stanowi wyzwanie z powodu niecodziennych wymagań (równoczesne zasilanie wielu użytkowników sprężonym powietrzem o różnych parametrach oraz konieczność uzyskiwania ekstremalnie dużych przepływów), do spełnienia których niezbędne jest zapewnienie zbiorników o odpowiedniej pojemności oraz zaawansowanego systemu sterowania. Opisany zostanie każdy z etapów projektu, ze szczególnym naciskiem na proces wyboru urządzeń technologicznych oraz rozwój systemu sterowania. Zaprezentowany system wytwarzania oraz dystrybucji sprężonego powietrza został zaimplementowany w Instytucie Lotnictwa w Warszawie, poprawiając jakość sprężonego powietrza dostarczanego do odbiorców oraz upraszczając proces planowania badań.

Słowa kluczowe: sprężone powietrze, laboratorium, tunel aerodynamiczny. 